\title{
No-Tillage and Phosphate Fertilization Management on Soybean Culture in Brazilian Cerrado
}

\author{
Robson da Costa Leite ${ }^{1}$, Rubson da Costa Leite ${ }^{2}$, Jefferson Santana da Silva Carneiro ${ }^{3}$, Gilson Araújo de Freitas ${ }^{1}$, \\ Antônio Carlos Martins dos Santos ${ }^{1}$, Rubens Ribeiro da Silva ${ }^{1} \&$ Antonio Clementino dos Santos ${ }^{2}$ \\ ${ }^{1}$ Federal University of Tocantins, Gurupi, Tocantins, Brazil \\ ${ }^{2}$ Federal University of Tocantins, Araguaína, Tocantins, Brazil \\ ${ }^{3}$ Federal University of Lavras, Minas Gerais, Brazil \\ Correspondence: Rubson da Costa Leite, Federal University of Tocantins, Araguaína, Tocantins, Brazil. Tel: \\ 55-63-999-579-410. E-mail: rubsonif@gmail.com
}

$\begin{array}{ll}\text { Received: February 16, } 2018 & \text { Accepted: March 11, } 2018 \quad \text { Online Published: April 15, } 2018 \\ \text { doi:10.5539/jas.v10n5p125 } & \text { URL: https://doi.org/10.5539/jas.v10n5p125 }\end{array}$

The research is financed by TIMAC Agro Brasil.

\begin{abstract}
Despite the benefits of no-till practices, soil compaction is a problem that can cause, among other things, mechanical impediment to root growth and less response to soil fertilization. The objective of this study was to evaluate the effect of subsoiling and doses of phosphate fertilization on soybean that have been cultivated over ten years under no-till systems in the Brazilian Cerrado. The experiment consisted of a randomized complete block design in a $2 \times 4$ factorial arrangement. Two managements in consolidated no-tillage area were considered: with and without subsoiling, along with four levels of phosphate fertilization: $0,100,300$ and $400 \mathrm{~kg} \mathrm{ha}^{-1}$ of $\mathrm{P}_{2} \mathrm{O}_{5}$. The practice of subsoiling in an area with ten years of no-till system provided an increase of $124.38 \mathrm{~kg} \mathrm{ha}^{-1}$ in soybean productivity. Soybean plants grown under no-tillage system, with subsoil management, showed better development and pod production. The maximum phosphorus efficiency, with subsoiling, was achieved with the dose of $172 \mathrm{~kg} \mathrm{ha}^{-1}$ of $\mathrm{P}_{2} \mathrm{O}_{5}$, yielding $5,693.4 \mathrm{~kg} \mathrm{ha}^{-1}$. In the no-tillage system, the maximum efficiency dose and crop yield were $159 \mathrm{~kg} \mathrm{ha}^{-1}$ of $\mathrm{P}_{2} \mathrm{O}_{5}$ and $5434.2 \mathrm{~kg} \mathrm{ha}^{-1}$, respectively.
\end{abstract}

Keywords: Glycine max, Western Bahia, subsoiling

\section{Introduction}

The Brazilian production of grains, which for many decades was carried out in a conventional tillage system (soil tillage), has been replaced by no-till system (Nunes et al., 2011; Reichert et al., 2016). No-tillage is a system of farming that consists of planting a narrow slit trench without tillage, leaving the crop residue on the field surface after harvest (Drescher et al., 2011).

Increased soil organic matter (Baker \& Saxton, 2006) by straw deposition, improved aggregate stability (Souza et al., 2010b) and soil quality erosion reduction (Bogunovic et al., 2018) are considered benefits of no-tillage systems. However, soil compaction is a problem in no-till areas due to intense traffic of machines for many years and the absence of soil rotation (Silva et al., 2008, 2012; Girardello et al., 2017), which can cause problems, such as mechanical impediment to plant root growth (Rosa et al., 2012) and increased surface runoff (Pohlitz et al., 2018).

In addition to the physical properties of the soil, such as increased density caused by compaction, Ribeiro et al. (2010) mention lower response of plants to fertilization, especially phosphate fertilization, since phosphorus becomes more adsorbed in the soil, causing diffusive flux reduction and require higher doses of phosphate fertilizers.

When compaction is identified in no-tillage area, it is necessary to proceed with a management system that aims at breaking the compacted layer, with minimal soil disturbance, leaving the crop residue on the field (Seki et al., 2015). Subsoiling is an alternative for soil decompaction, without compromising the straw residues. The mechanical mobilization caused by this implement provides good physical conditions for root development, with higher aeration and hydraulic conductivity, resulting in increased agricultural productivity (Pesini et al., 2014). 
Therefore, work is needed to evaluate the effect of subsoiling in no-tillage area along with soil response under phosphorus application. This study aimed at assessing the effect of subsoiling and different doses of phosphate fertilization on soybean cultivated under no-tillage system for ten years, in the Brazilian Cerrado.

\section{Material and Methods}

\subsection{Experimental Conditions}

The study was carried out during the end of 2014 and early 2015 (2014/2015 season), in São Desidério, Bahia $\left(12^{\circ} 58^{\prime} 15.6^{\prime \prime} \mathrm{S}\right.$ and $\left.46^{\circ} 04^{\prime} 38.1^{\prime \prime} \mathrm{W}\right)$. The climate of the region is Aw (hot and humid), according to the Köppen International Classification (Alvares et al., 2013), with an average annual rainfall of 1,400 $\mathrm{mm}$. The soil of the experimental area presents Free Sand texture (Table 1), classified as Orthic Quartzarenic Neosol (Embrapa, 2013).

Table 1. Soil chemical and physical parameters, São Desiderio-BA

\begin{tabular}{|c|c|c|c|c|c|c|c|c|c|c|c|c|c|}
\hline $\mathrm{pH}$ & $P$ & $\mathrm{~K}$ & $\mathrm{Ca}$ & $\mathrm{Mg}$ & $\mathrm{Al}$ & $\mathrm{H}+\mathrm{Al}$ & $\mathrm{SB}$ & $\mathrm{CEC}$ & V\% & $\mathrm{m} \%$ & Sand & Silt & Clay \\
\hline $\mathrm{CaCl}_{2}$ & \multicolumn{2}{|c|}{$-m g d^{-3}-$} & & & $-\bar{c}$ & $l_{\mathrm{c}} \mathrm{dm}^{-3}$ & & $\cdots$ & & & \multicolumn{3}{|c|}{ - } \\
\hline 5.4 & 38 & 58 & 1.8 & 0.8 & 0.0 & 1.5 & 2.7 & 4.25 & 64 & 0.0 & 83 & 2.4 & 14.6 \\
\hline
\end{tabular}

\subsection{Experimental Design and Data Collection}

The experiment consisted of a randomized complete block design in a $2 \times 4$ factorial arrangement, with five replicates. The first factor was related to tenure management systems consolidated for ten years (with and without subsoiling) and the second to levels of phosphate fertilization $\left(0,100,300\right.$ and $400 \mathrm{~kg} \mathrm{ha}^{-1}$ of $\left.\mathrm{P}_{2} \mathrm{O}_{5}\right)$, using the Basiduo ${ }^{\mathbb{B}}$ fertilizer. Each experimental unit corresponded to $100 \mathrm{~m}^{2}$, totaling an area of $4,000 \mathrm{~m}^{2}$.

Prior to experiments, the soil resistance to penetration test was performed (Figure 1) in depths with difficulty root plant growth (greater than $2 \mathrm{Mpa}$ ), according to Beuther et al. (2006). A semi-automatic mechanical penetrograph (values adjusted according to soil moisture) was used with the number of samplings recommended by Tavares Filho and Ribon (2008).

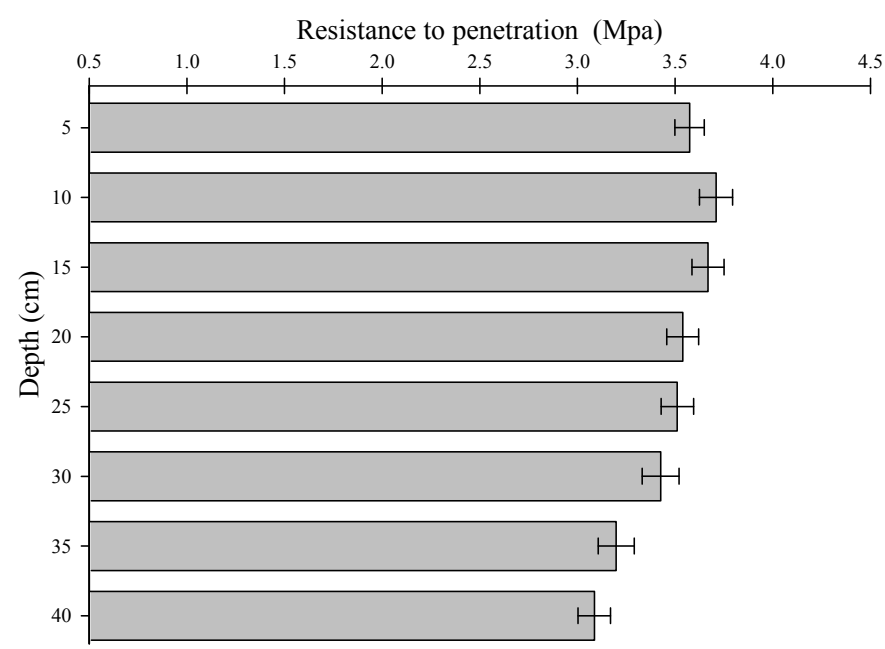

Figure 1. Soil resistance to penetration (RSP) in no-till area. São Desidério-BA, 2015

No-till system has been applied to the area for nearly ten consecutive years, with soybean rotation, and corn intercropped with Brachiaria, followed by subsequent cotton crop. The plots of the experiment that received subsoiling were managed with a rod-type implemented at $38 \mathrm{~cm}$ depth. Phosphorus doses were applied (in the sowing line) at the time of planting, according to each treatment.

The cultivar used in the experiment was Monsoy 8372 Ipro, at a spacing of $45 \mathrm{~cm}$ between rows, using approximately 16 plants $\mathrm{m}^{-1}$. During the experiment period sprays with insecticides, fungicides, herbicides and foliar micronutrients were carried out following the monitoring and management recommendations for the 
soybean crop of the state of Bahia. Climatic data were collected throughout the experimental period (December 2014 through May 2015) (Figure 2).

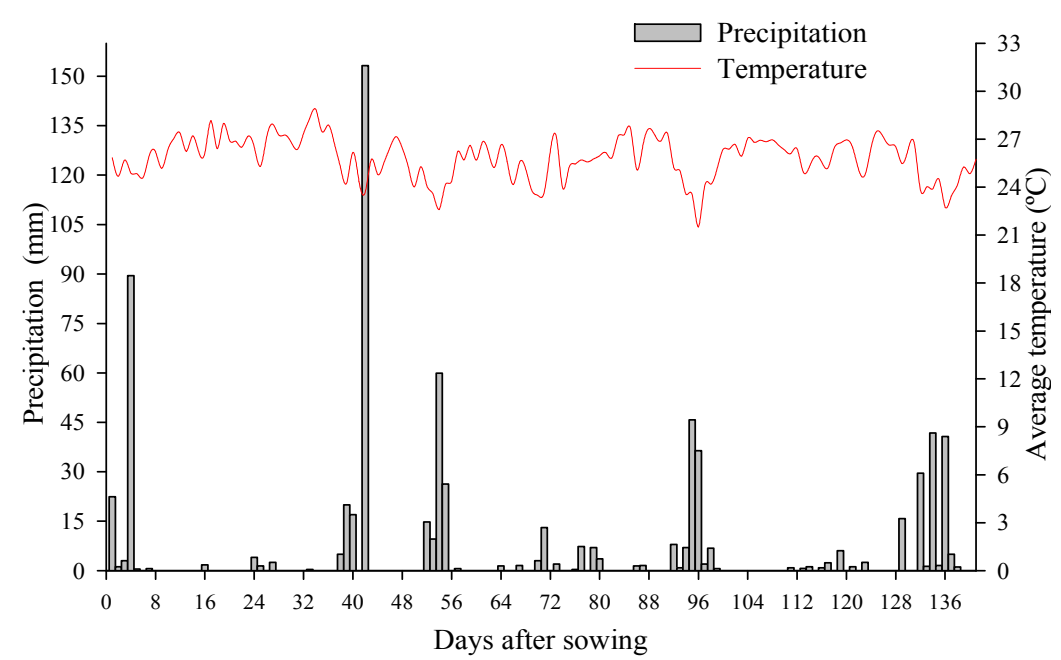

Figure 2. Temperature and precipitation during the experiment period (2014/15 season) in the Santa Rosa farm in São Desidério-BA

Harvest was performed manually by pulling out the central lines of each plot, excluding the borders. The production indicators evaluated were: plant height $(\mathrm{PH})$; first pod insertion height $(\mathrm{FPIH})$; number of pods per plant (NPP); number of beans per pod (NBP); weight of one thousand grains (WOG) and productivity (P). Plant and first pod insertion height were determined by direct measurement, using a ruler graduated in millimeters. The number of pods per plant and the number of grains per pod were determined by manually counting these indicators in the studied plants. The weight of one thousand grains was determined on a precision scale. The productivity was determined based on the grain yield of the plants harvested in each experiment, adjusted to $13 \%$ of humidity, which was corrected from the spacing and quantity of plants per meter, transformed to $\mathrm{kg} \mathrm{ha}^{-1}$.

\subsection{Statistical Analysis}

All data were tested for normality (Shapiro-Wilk) and homoscedasticity. The F test was applied for the qualitative data (management), and when significant, the Tukey test $(\mathrm{p}<0.01)$ was applied. Regression analysis was performed for the quantitative data (doses of phosphorus).

\section{Results and Discussion}

\subsection{Soybean Production According to the Management}

The results of the analysis of variance showed significance for plant height, number of pods per plant, number of grains per pod and plant productivity. There was no significance for any of the analyzed variables regarding the interaction between management systems and phosphorus doses.

Overall, plants were higher $(92 \mathrm{~cm})$ when subsoiling was applied in the no-tillage area (Figure 3A), representing an increase of $15 \%$ in comparison to plants of the no-tillage area, without subsoiling $(80 \mathrm{~cm})$. 

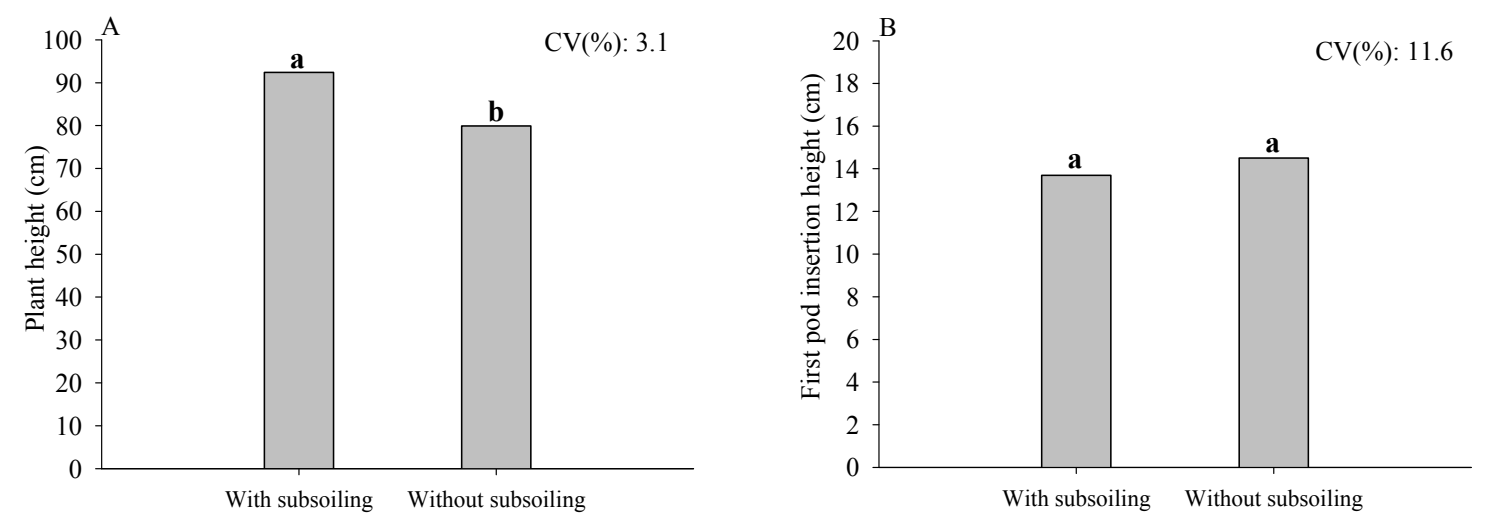

Figure 3. Plant height (A) first pod insertion height (B) in soybean under the cultivation systems. São Desiderio-BA, 2015

Note. Averages followed by the same letter do not significantly differ by the Tukey test $(\mathrm{p}<0.01)$.

The height gain of plants in area with subsoiling may be related to better root development in decompressed soils, allowing a better exploration and greater contact of the roots with the soil, which increases water and nutrients absorption by the plant. Compacted soil from no-till consolidation can influence $55 \%$ on height reduction of soybean plants (Lima et al., 2010).

When studying the soybean response to increased soil compaction caused by no-tillage consolidation and phosphate fertilization rates, Ribeiro et al. (2010) observed that there was a reduction in plant growth due to higher soil density. These authors attributed the lower soybean growth to the reduction of the diffusive flux of $\mathrm{P}$ in soils.

For the first pod insertion height (FPIH), there was no influence of the management systems (Figure 3B). The plants presented FPIH of 14 and $15 \mathrm{~cm}$ for no-tillage systems with and without subsoiling, respectively. None of the evaluated systems presented FPIH less than $12 \mathrm{~cm}$, which could be harmful to soybean yield and purity of harvested grains (Carvalho et al., 2010).

For the number of pods per plant (NPP), plants from area with subsoil application presented higher number of pods when compared to the area without subsoiling (Figure 4A).
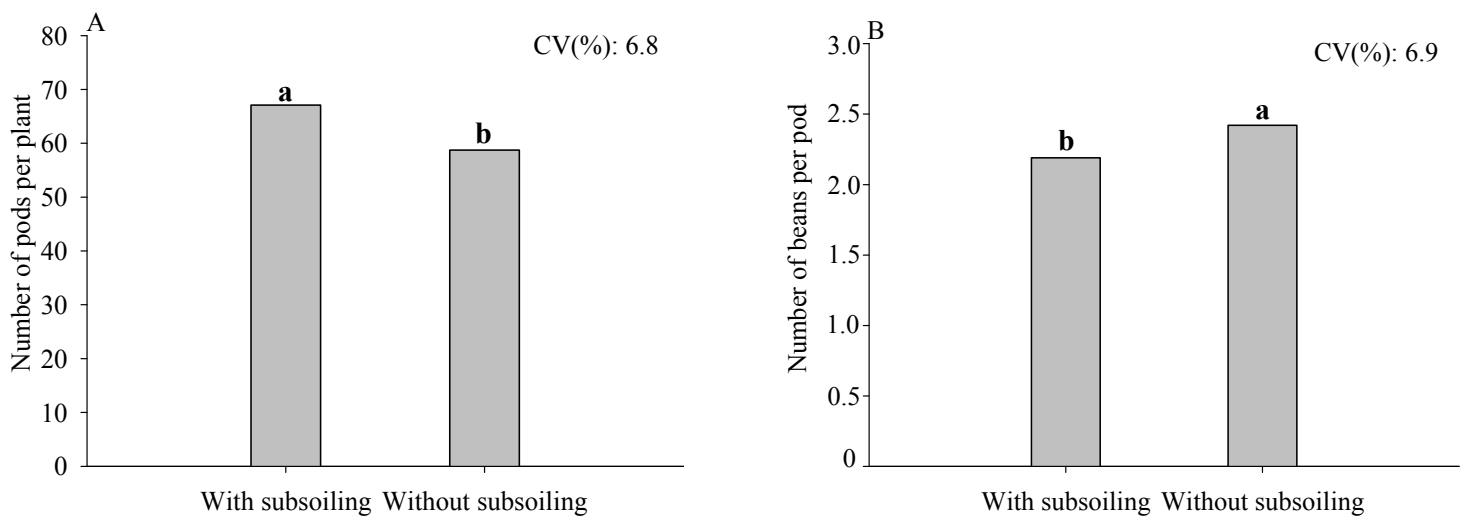

Figure 4. Number of pods per plant (A) and number of beans per pod (B) in soybean. São Desiderio-BA, 2015 Note. Averages followed by the same letter do not significantly differ by the Tukey test $(\mathrm{p}<0.01)$.

The subsoiling practice provided $14 \%$ more pods in relation to no-tillage without subsoiling, which can be due to better response to fertilization with soil rotation (Ribeiro et al., 2010) and/or efficiency in the absorption of nutrients from better root development, caused by the breaking of the compacted layer in the soil. 
When studying different cropping systems, Souza et al. (2010b), found a significant effect of management on NPP. These authors observed that conventional tillage was superior to no-tillage conservation practices, and the no-till area showed higher soil density, which can have probably influenced this characteristic in soybean plants.

In a study evaluating soil compaction levels in soybean, Centurion et al. (2006) observed a negative linear effect for soybean pod production as a function of increased soil density. The study demonstrated that soil compaction has a direct effect on the amount of pods per plant in soybean.

Regarding the number of beans per pod (NBP), the area with no-tillage and without subsoiling showed higher results when compared to the practice of subsoiling in the no-tillage area (Figure 4B).

The practice of subsoiling resulted in 2.2 beans per pod, which is $10 \%$ lower than the no-till area ( 2.4 beans per pod). The number of beans per pod has a direct influence on soybean yield.

The NBP is a genotypic character and has little influence on the environment (Karasu et al., 2009; Souza et al., 2010a). However, under restrictive conditions to the development of the culture, there may be influence of the environment on the NBP (Leite et al., 2017).

The weight of one thousand grains (WOG) had no influence on the evaluated systems, presenting similar values (Figure 5A). The subsoiling area presented $156 \mathrm{~g}$ for WOG, while the area without subsoiling management presented $153 \mathrm{~g}$ of WOG.
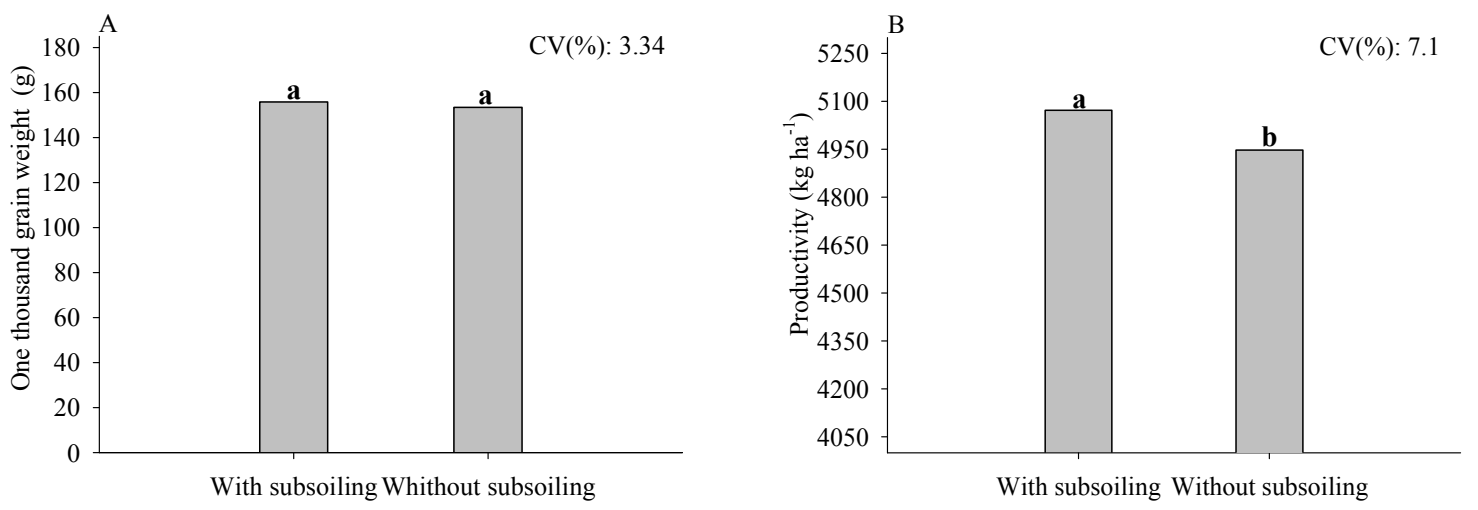

Figure 5. One thousand grain weight (A) and Productivity (B) of soybean. São Desiderio-BA, 2015

Note. Averages followed by the same letter do not significantly differ by the Tukey test $(\mathrm{p}<0.01)$.

Corroborating the results found in the present study, Souza et al. (2010) found no influence of compaction on the weight of soybean grains. Certainly, the lower pod production occurred in the area without subsoiling allowed WOG values similar to the compacted area, since the lower number of grains in the plants required less nutrients for the grains.

The yield of soybean plants under no-tillage cultivation with subsoiling management presented an average of $5,072 \mathrm{~kg} \mathrm{ha}^{-1}$, while for the no-till area, the average yield was $4,948 \mathrm{~kg} \mathrm{ha}^{-1}$. This difference between the productivity of the cropping systems is equivalent to 2 bags ha $^{-1}(1$ bag represents $60 \mathrm{~kg}$ ). The productivity (P) with subsoiling management was superior to non-subsoiling due to the superior results in WOG and P, since other productivity factors were equal and lower than NPB.

In studies on soybean yield and changes in soil physical attributes as a function of cropping systems, Girardello et al. (2011) and Nicoloso et al. (2008) concluded that the use of the scarifier in a system of no-tillage was $7 \%$ higher than the no-tillage system.

A good nutrition and adequate water supply to plants make it possible to express its maximum productive potential. A compacted soil directly influences the absorption of nutrients and water by plants due to lower root development (Centurion et al., 2006). Possibly, the practice of subsoiling in the area solved the problem of compaction and allowed soybean plants to express their maximum productive potential and, consequently, higher productivity. 


\subsection{Production of Soybean as a Function of Phosphate Fertilizer}

In relation to the phosphate fertilizer doses in the cultivation systems, all variables presented adjustment to the regression models.

The height of plants presented an adjustment to the quadratic model as a function of the doses of phosphate fertilizer for the two systems evaluated (Figure 6A). The maximum height of plants in the subsoiling area was obtained with the application of $200 \mathrm{~kg} \mathrm{ha}^{-1}$ of $\mathrm{P}_{2} \mathrm{O}_{5}$, reaching $98 \mathrm{~cm}$, which represents an increase of $8 \%$ in relation to plants that did not receive phosphate fertilization. The area under no-tillage practices resulted in maximum response for the dose of $191 \mathrm{~kg} \mathrm{ha}^{-1}$ of $\mathrm{P}_{2} \mathrm{O}_{5}$, reaching $87 \mathrm{~cm}$ in height.
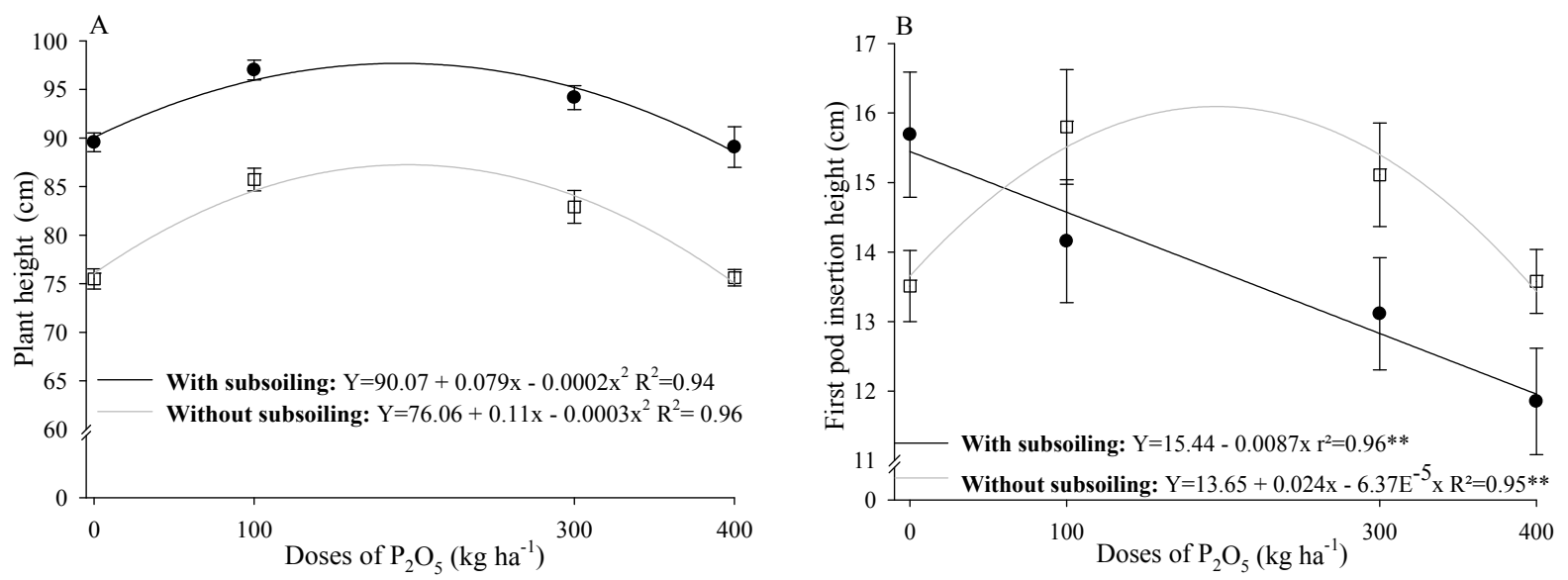

Figure 6. Plant height (A) and first pod insertion height (B) of soybean as a function of doses of phosphate fertilization in crop systems in São Desiderio-BA

Comparing the two evaluated systems, the control dose of the subsurface area $\left(0 \mathrm{~kg} \mathrm{ha}^{-1}\right.$ of $\left.\mathrm{P}_{2} \mathrm{O}_{5}\right)$ was higher than the maximum efficiency dose $\left(191 \mathrm{~kg} \mathrm{ha}^{-1} \mathrm{P}_{2} \mathrm{O}_{5}\right)$ of the area without subsoiling. These values demonstrate higher efficiency of phosphate fertilization in subsoiling tillage area even with adequate $\mathrm{P}$ levels in the soil.

The FPIH presented an adjustment to the linear model, decreasing as a function of phosphorus doses applied in the no-till with subsoiling area, since the area without subsoiling presented an adjustment to the quadratic model (Figure 6B). The maximum response of phosphate fertilization was obtained in the no-tillage system without subsoiling, in which plants reached FPIH of $16 \mathrm{~cm}$ with $196 \mathrm{~kg} \mathrm{ha}^{-1}$ of $\mathrm{P}_{2} \mathrm{O}_{5}, 16 \%$ higher for the treatment without phosphate fertilization. For the no-till area, there was a reduction of $0.87 \mathrm{~cm}$ of FPIH for each $100 \mathrm{~kg}$ of applied $\mathrm{P}_{2} \mathrm{O}_{5}$.

The NPP presented adjustment to the quadratic model as a function of phosphorus doses for both systems (Figure 7A). Tillage without subsoiling showed a $3 \%$ increase in relation to the control $\left(0 \mathrm{~kg} \mathrm{ha}^{-1}\right.$ of $\left.\mathrm{P}_{2} \mathrm{O}_{5}\right)$, producing 61 pods per plant at the maximum efficiency dose of $158 \mathrm{~kg} \mathrm{ha}^{-1}$ of $\mathrm{P}_{2} \mathrm{O}_{5}$. However, the subsoiling practice was $16 \%$ higher in pod production per plant when compared to the control $\left(0 \mathrm{~kg} \mathrm{ha}^{-1}\right.$ of $\left.\mathrm{P}_{2} \mathrm{O}_{5}\right)$, with maximum efficiency dose of $187 \mathrm{~kg} \mathrm{ha}^{-1}$ of $\mathrm{P}_{2} \mathrm{O}_{5}$ and producing 75 pods per plant. 

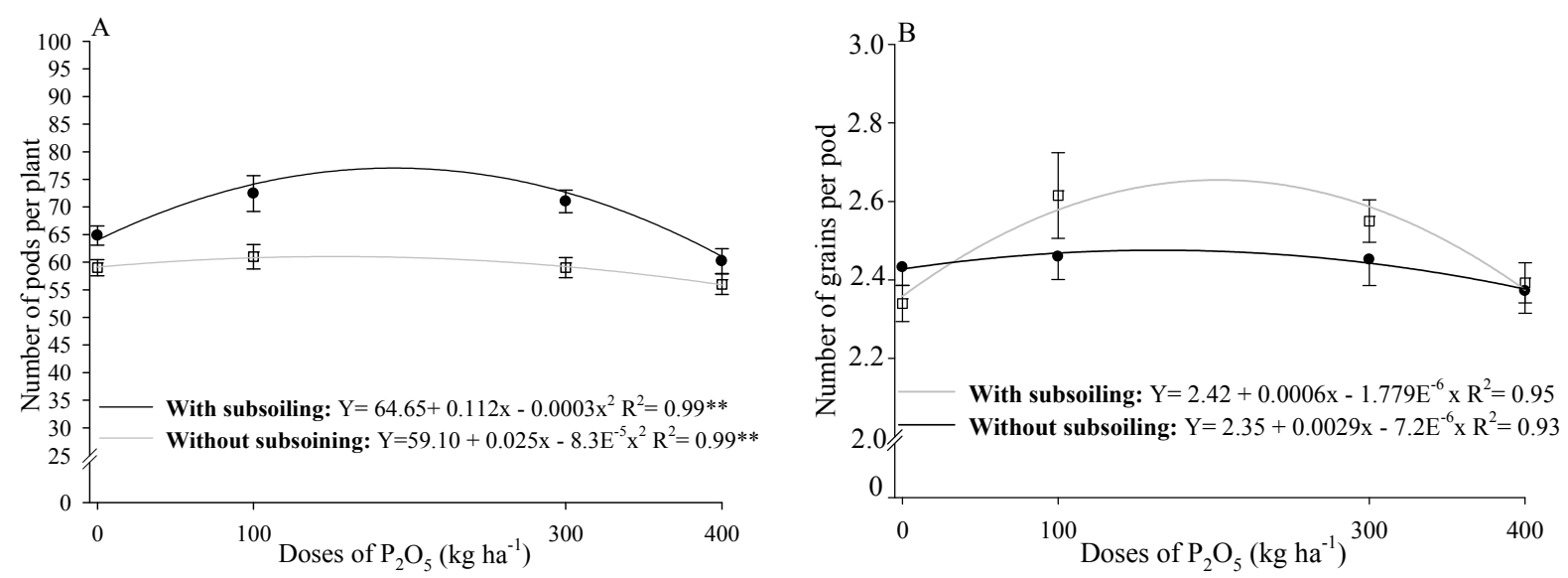

Figure 7. Number of pods per plant (A) and number of grains per pod (B) of soybean as a function of phosphate fertilization doses in crop systems in São Desidério-BA

The NBP presented adjustment to the quadratic model as a function of phosphorus doses in no-tillage with and without subsoiling (Figure 7B). The area under no-till system showed higher results, with a maximum efficiency dose of $201 \mathrm{~kg} \mathrm{ha}^{-1}$ of $\mathrm{P}_{2} \mathrm{O}_{5}$, resulting in 2.6 grains per pod, which represents an increase of $8 \%$ in relation to the control $\left(0 \mathrm{~kg} \mathrm{ha}^{-1}\right.$ of $\left.\mathrm{P}_{2} \mathrm{O}_{5}\right)$. The plants under no-tillage with subsoiling had a $4.8 \%$ increase in relation to the control $\left(0 \mathrm{~kg} \mathrm{ha}^{-1}\right.$ of $\left.\mathrm{P}_{2} \mathrm{O}_{5}\right)$; however, a maximum response was obtained at the dose of $169 \mathrm{~kg} \mathrm{ha}^{-1}$ of $\mathrm{P}_{2} \mathrm{O}_{5}$, producing 2.5 beans per pod.

The WOG presented a quadratic model as a function of doses of phosphate fertilizer for no-tillage with subsoiling. For the no-till area, the model was linear (Figure 8A). The highest WOG were observed in the treatments with subsoiling, in which the maximum efficiency dose was $262 \mathrm{~kg} \mathrm{ha}^{-1}$ of $\mathrm{P}_{2} \mathrm{O}_{5}$, with an average production of $161 \mathrm{~g}$, which significantly contributes to the productivity of the experiment.
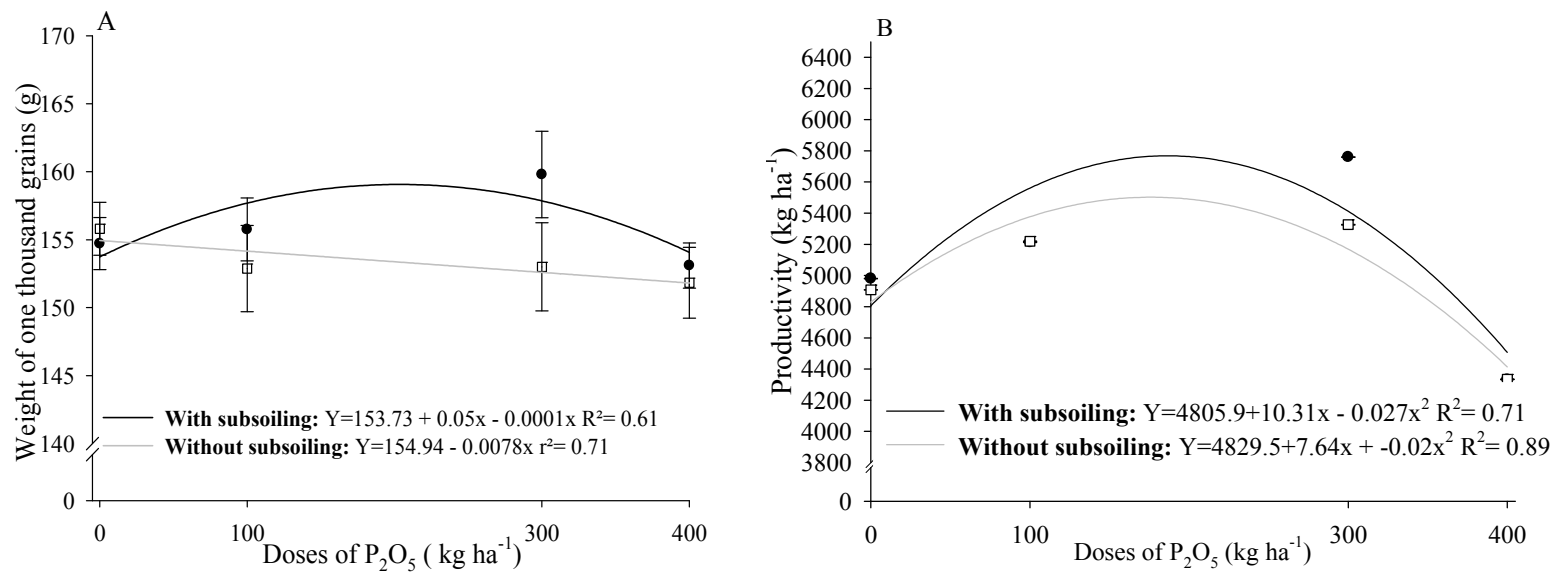

Figure 8. Weight of one thousand grains (A) and productivity (B) of soybean as a function of phosphate fertilization doses in crop systems in São Desidério-BA

The productivity presented a quadratic model as a function of doses of phosphate fertilizer in no-till with and without subsoiling (Figure 8B). At the maximum efficiency dose of $172 \mathrm{~kg} \mathrm{ha}^{-1}$ of $\mathrm{P}_{2} \mathrm{O}_{5}$, an average of 5,693 $\mathrm{kg}$ $\mathrm{ha}^{-1}$ was produced for plants under no-tillage with subsoiling, which indicates an increase of $18 \%$ in relation to the control $\left(0 \mathrm{~kg} \mathrm{ha}^{-1}\right.$ of $\left.\mathrm{P}_{2} \mathrm{O}_{5}\right)$. The maximum productive efficiency of the area under no-till without subsoil management was $159 \mathrm{~kg} \mathrm{ha}^{-1}$ of $\mathrm{P}_{2} \mathrm{O}_{5}$, yielding $5,434 \mathrm{~kg} \mathrm{ha}^{-1}$. These results demonstrate an increment of 4.3 bags $\mathrm{ha}^{-1}$ with the practice of subsoil allied to phosphate fertilization. 
Even with optimum levels of phosphorus in the soil in the experimental area (Table 1), the productive gain with the maximum phosphorus dose, efficiency reached an addition of 17 and 12 bags ha $^{-1}$, with and without subsoiling, respectively, when compared to the absence of phosphate fertilization.

Phosphorus presents low mobility in the soil, thus, with no-tillage, the tendency is that phosphorus remains in the superficial layers, affecting its bioavailability in deeper layers (Nunes et al., 2011), which justifies the response of plants as a function of phosphate fertilization in no-tillage areas with adequate P levels in the soil.

Subsoil management in no-tillage systems has the potential to reduce compaction, improving soil structure, with a residual effect of up to two and a half years after the intervention (Drescher et al., 2011). Several studies (Drescher et al., 2011; Nunes et al., 2011) show that soil rotation in no-tillage area compacted by incorrect handling and heavy machine traffic has shown beneficial effects to the structural and chemical aspects of the soil, with better use of fertilizers.

\section{Conclusions}

The practice of subsoiling in an area with ten years of no-tillage system provided an increase of $125 \mathrm{~kg} \mathrm{ha}^{-1}$ in soybean productivity.

Soybean plants grown under no-tillage system with subsoil management, showed better development and pod production.

The dose of maximum phosphorus efficiency in no-tillage area with subsoiling was $172 \mathrm{~kg} \mathrm{ha}^{-1}$ of $\mathrm{P}_{2} \mathrm{O}_{5}$, with a productivity of $5,693 \mathrm{~kg} \mathrm{ha}^{-1}$. In the no-tillage area without subsoiling, the maximum efficiency dose was $159 \mathrm{~kg}$ $\mathrm{ha}^{-1}$ of $\mathrm{P}_{2} \mathrm{O}_{5}$ with a yield of $5,434 \mathrm{~kg} \mathrm{ha}^{-1}$.

\section{Acknowledgements}

This work was financed by TIMAC Agro Brasil. We thank the Federal University of Tocantins for their collaboration in the collection of experimental data.

\section{References}

Alvares, C. A., Stape, J. L., Sentelhas, P. C., Gonçalves, J. L. De M., \& Sparovek, G. (2013). Köppen's climate classification map for Brazil. Meteorologische Zeitschrift, 22, 711-728. https://doi.org/10.1127/0941-2948/ 2013/0507

Baker, C. J., \& Saxton, K. E. (2006). No-tillage seeding in conservation agriculture. No-Tillage Seeding: Science and Practice. https://doi.org/10.1079/9781845931162.0000

Bogunovic, I., Pereira, P., Kisic, I., Sajko, K., \& Sraka, M. (2018). Tillage management impacts on soil compaction, erosion and crop yield in Stagnosols (Croatia). Catena, 160, 376-384. https://doi.org/10.1016/ j.catena.2017.10.009

Carvalho, E. R., Resende, P. M., Ogoshi, F. G. A., Botrel, E. P., Alcantra, H. P., \& Santos, J. P. (2010). Desempenho de cultivares de soja [Glycine max (L.) Merril] em cultivo de verão no sul de Minas Gerais. Ciência e Agrotecnologia, 34(4), 892-899. https://doi.org/10.1590/S1413-70542010000400014

Centurion, J. F., Centurion, M. A. P. Da C., Beutler, A. N., Rossini, L. A., Freddi, O. Da S., \& Souza Neto, E. L. De. (2006). Compactação do solo no desenvolvimento e na produção de cultivares de soja. Científica, 34 , 203-209.

Drescher, M. S., Eltz, F. L. F., Denardin, J. E., \& Faganello, A. (2011). Persistência do efeito de intervenções mecânicas para a descompactação do solo em sistemas de plantio direto. Revista Brasileira de Ciência do Solo, 35(5), 1713-1722. https://doi.org/10.1590/S0100-06832011000500026

EMBRAPA. (2013). Sistema Brasileiro de Classificação de Solos (3rd ed., p. 353). Centro Nacional de Pesquisa em Solos, Rio de Janeiro.

Girardello, C., Amado, T. J. C., Luis, A. S., Lanzanova, E. M., \& Tasca, A. (2017). Resistência do solo à penetração e desenvolvimento radicular da soja sob sistema plantio direto com tráfego controlado de máquinas agrícolas. Scientia Agraria, 18(2), 86-96. https://doi.org/10.5380/rsa.v18i2

Girardello, V. C., Amado, T. J. C., Nicoloso, R. S., Hörbe, T. A. N., Ferreira, A. O., Tabaldi, F. M., \& Lanzanova, M. E. (2011). Alterações nos atributos físicos de um latossolo vermelho sob plantio direto induzidas por diferentes tipos de escarificadores e o rendimento da soja. Revista Brasileira de Ciência do Solo, 35(6), 2115-2126. https://doi.org/10.1590/S0100-06832011000600026 
Karasu, A., Oz, M., Goksoy, A. T., \& Turan, Z. M. (2009). Genotype by environment interactions, stability, and heritability of seed yield and certain agronomical traits in soybean [Glycine max (L.) Merril.]. African Journal of Biotechnology, 8(4), 580-590.

Leite, R. C., Carneiro, J. S. S., Freitas, G. A., Casali, M. E., \& Silva, R. R. (2017). Adubação fosfatada na soja durante três safras consecutivas na nova fronteira agrícola brasileira. Scientia Agraria, 18(4), 28-35. https://doi.org/10.5380/rsa.v18i4

Lima, C. L. R., Reinert, D. J., Reichert, J. M., \& Suzuki, L. E. A. S. (2010). Produtividade de culturas e resistência à penetração de Argissolo Vermelho sob diferentes manejos. Revista Pesquisa Agropecuária Brasileira, 45(1), 89-98. https://doi.org/10.1590/S0100-204X2010000100012

Nicoloso, R. S., Amado, T. J. C., Schneider, S., Lanzanova, M. E., Girardello, V. C., \& Bragagnolo, J. (2008). Eficiência da escarificação mecânica e biológica na melhoria dos atributos físicos de um latossolo muito argiloso e no incremento do rendimento de soja. Revista Brasileira de Ciência do Solo, 32(4), 1723-1734. https://doi.org/10.1590/S0100-06832008000400037

Nunes, R. S., Sousa, D. M. G., Goedert, W. J., \& Vivaldi, L. J. (2011). Distribuição de fósforo no solo em razão do sistema de cultivo e manejo da adubação fosfatada. Revista Brasileira de Ciência do Solo, 35, 877-888. https://doi.org/10.1590/S0100-06832011000300022

Pesini, F., Rosa, D. P., Santos, C. C., Fincatto, D., Pagnussat, L., \& Bruinsma, M. L. (2014). Uso de subsolador como técnica de melhoria física de um solo sob sistema plantio direto em sertão (RS). RAMVI, 1(1), 11.

Pöhlitz, J., Rücknagel, J., Koblenz, B., Schlüter, S., Vogel, H. J., \& Christen, O. (2018). Computed tomography and soil physical measurements of compaction behaviour under strip tillage, mulch tillage and no tillage. Soil and Tillage Research, 175, 205-216. https://doi.org/10.1016/j.still.2017.09.007

Reichert, J. M., Rosa, V. T., Vogelmann, E. S., Rosa, D. P., Horn, R., Reinert, D. J., Sattler, A., \& Denardin, J. E. (2016). Conceptual framework for capacity and intensity physical soil properties affected by short and long-term (14 years) continuous no-tillage and controlled traffic. Soil and Tillage Research, 158, 123-136. https://doi.org/10.1016/j.still.2015.11.010

Ribeiro, M. A. V., Novais, R. F., Faquin, V., Ferreira. M. M., Furtini Neto, A. E., Lima, J. M., \& Villani, E. M. A. (2010). Resposta da soja e do eucalipto ao aumento da densidade do solo e a doses de fósforo. Revista Brasileira de Ciência do Solo, 34, 1157-1164. https://doi.org/10.1590/S0100-06832010000400015

Rosa, D. P., Reichert, J. M., Mentges, M. I., Rosa, V. T., Vieira, D. A., \& Reinert, D. J. (2012). Demanda de tração e propriedades físicas de um Argissolo em diferentes manejos e intensidades de tráfego. Revista Pesquisa Agropecuária Brasileira, 47(1), 118-126. https://doi.org/10.1590/S0100-204X2012000100016

Seki, A. S., Seki, F. G., Jasper, S. P., Silva, P. R. A., \& Benez, S. H. (2015). Effects of soil decompaction techniques in an area under a system of direct seeding. Revista Ciência Agronômica, 46(3), 460-468. https://doi.org/10.5935/1806-6690.20150027

Silva, S. G. C., Silva, Á. P., Giarola, N. F. B., Tormena, C. A., \& Sá, J. C. De M. (2012). Temporary effect of chiseling on the compaction of a Rhodic Hapludox under no-tillage. Revista Brasileira de Ciência Do Solo, 36, 547-555. https://doi.org/10.1590/S0100-06832012000200024

Souza, C. A., Gava, F., Casa, R. T., Bolzan, J. M., \& Kuhnem Junior, P. R. (2010a). Relação entre densidade de plantas e genótipos de soja roundup ready. Planta Daninha, 28(4), 887-896. https://doi.org/10.1590/ S0100-83582010000400022

Souza, F. R., Junior, E. J. R., Fietz, C. R., Bergamin, A. C., Venturoso, L. R., \& Rosa, Y. B. C. J. (2010b). Atributos físicos e desempenho agronômico da cultura da soja em um latossolo vermelho distroférrico submetido a dois sistemas de manejos. Ciência Agrotecnologia, 34(6), 1357-1364. https://doi.org/10.1590/ S1413-70542010000600001

Tavares Filho, J., \& Ribon, A. A. (2008). Resistência do solo à penetração em resposta ao número de amostras e tipo de amostragem. Revista Brasileira de Ciência do Solo, 32, 487-494. https://doi.org/10.1590/S0100-06 832008000200003 


\section{Copyrights}

Copyright for this article is retained by the author(s), with first publication rights granted to the journal.

This is an open-access article distributed under the terms and conditions of the Creative Commons Attribution license (http://creativecommons.org/licenses/by/4.0/). 